\title{
Nuclear Factor- $\kappa$ B Modulates the p53 Response in Neurons Exposed to DNA Damage
}

\author{
Hossein Aleyasin, Sean P. Cregan, Grace Iyirhiaro, Michael J. O’Hare, Steve M. Callaghan, Ruth S. Slack, and \\ David S. Park \\ Ottawa Health Research Institute, Neurosciences, East Division, Ottawa, Ontario, Canada K1H 8M5
}

Previous studies have shown that DNA damage-evoked death of primary cortical neurons occurs in a p53 and cyclin-dependent kinasedependent (CDK) manner. The manner by which these signals modulate death is unclear. Nuclear factor- $\kappa \mathrm{B}(\mathrm{NF}-\kappa \mathrm{B})$ is a group of transcription factors that potentially interact with these pathways. Presently, we show that NF- $\kappa B$ is activated shortly after induction of DNA damage in a manner independent of the classic $\mathrm{I} \kappa \mathrm{B}$ kinase (IKK) activation pathway, CDKs, ATM, and p53. Acute inhibition of NF- $\kappa \mathrm{B}$ via expression of a stable I $\kappa$ B mutant, downregulation of the p $65 \mathrm{NF}-\kappa \mathrm{B}$ subunit by RNA interference (RNAi), or pharmacological NF- $\kappa \mathrm{B}$ inhibitors significantly protected against DNA damage-induced neuronal death. NF- $\kappa B$ inhibition also reduced p53 transcripts and p53 activity as measured by the p53-inducible messages, Puma and Noxa, implicating the p53 tumor suppressor in the mechanism of $\mathrm{NF}-\kappa \mathrm{B}$-mediated neuronal death. Importantly, p53 expression still induces death in the presence of NF- $\kappa \mathrm{B}$ inhibition, indicating that p53 acts downstream of NF- $\kappa$ B. Interestingly, neurons cultured from p 65 or p $50 \mathrm{NF}-\kappa \mathrm{B}$-deficient mice were not resistant to death and did not show diminished p53 activity, suggesting compensatory processes attributable to germline deficiencies, which allow p53 activation still to occur. In contrast to acute NF- $\kappa$ B inhibition, prolonged NF- $\kappa$ B inhibition caused neuronal death in the absence of DNA damage. These results uniquely define a signaling paradigm by which NF- $\kappa$ B serves both an acute $\mathrm{p} 53$-dependent pro-apoptotic function in the presence of DNA damage and an anti-apoptotic function in untreated normal neurons.

Key words: embryonic cortical neurons; NF- $\kappa$ B; camptothecin; p53; DNA damage; I $\kappa$ B; apoptosis

\section{Introduction}

DNA damage is an important component of neuropathological conditions. For example, DNA strand breaks have been reported in neurons after reperfusion of ischemic tissue, well in advance of DNA fragmentation caused by the apoptotic process (Tobita et al., 1995; Chen et al., 1997; Cui et al., 2000). DNA damage also has been reported in other chronic neurodegenerative conditions such as Parkinson's (Robison and Bradley, 1984; Alam et al., 1997; Jenner, 1998), Huntington's, and Alzheimer's diseases (Gabbita et al., 1998; Mecocci et al., 1998; Lovell and Markesbery, 2001) and amyotrophic lateral sclerosis (ALS) (Robison and Bradley, 1984; Bogdanov et al., 2000). In this regard, elements known to be relevant to DNA damage, such as poly(ADP-ribose) polymerase (PARP) and p53, have been implicated in a variety of models of neurodegenerative disease (Morrison et al., 1996; Cosi et al., 1997; Cosi and Marien, 1999). The importance of DNA damage is illustrated further by the observation that mice deficient in a variety of DNA damage repair pathways display aberrant neuronal loss and impaired neurodevelopment (Barnes et

Received Sept. 9, 2003; revised Feb. 7, 2004; accepted Feb. 7, 2004.

This work was supported by the Canadian Institute of Health Research (CIHR; D.S.P. and R.S.S.), the Heart and Stroke Foundation of Canada (D.S.P.), and the Canadian Stroke Network (D.S.P.). D.S.P. is a CIHR scholar. We thank Elizabeth Keramaris and Jason MacLaurin for their technical support. We also thank Dr. M. Tymianski (Toronto Western) for technical advice.

Correspondence should be addressed to Dr. David Park, Ottawa Health Research Institute, Neurosciences, East Division, 451 Smyth Road, 0ttawa, Ontario, Canada K1H 8M5. E-mail: dpark@uottawa.ca.

DOI:10.1523/JNEUROSCI.0155-04.2004

Copyright $\odot 2004$ Society for Neuroscience $\quad$ 0270-6474/04/242963-11\$15.00/0 al., 1998; Gao et al., 1998; Deans et al., 2000; Gu et al., 2000; Sugo et al., 2000). Taken together, this evidence implicates DNA damage as one key initiator of neuronal death. However, the mechanism or mechanisms that regulate this death are not fully understood.

Neuronal death is controlled by a complex series of events, which include both pro-apoptotic and anti-apoptotic signals. To examine the fundamental signals induced by DNA damage, we have used the paradigm of cortical neuronal death initiated by exposure to the topoisomerase 1 inhibitor, camptothecin. In this model, death is dependent on at least two proximal signals, the tumor suppressor $\mathrm{p} 53$ and the cell cycle-related cyclin-dependent kinases (CDKs) (Park et al., 1998). These signals work in concert to control Bax translocation and activation of the apoptosome. However, it is likely that numerous other signals implicated in neuronal death are regulated by DNA damage also. Because it is the balance of all signals that control death, it has become important to delineate additional death/survival-promoting elements and ascertain how they are linked to the growing signaling picture.

One fundamental signal that has played an important role in cell death/survival is nuclear factor- $\kappa \mathrm{B}(\mathrm{NF}-\kappa \mathrm{B})$. Members of $\mathrm{Rel} / \mathrm{NF}-\kappa \mathrm{B}$ family of transcription factors regulate diverse processes such as inflammation, cell cycle, and apoptosis. The active form of NF- $\kappa \mathrm{B}$ is a dimeric molecule composed of two subunits from the Rel/NF- $\kappa$ B family, including Rel-A (p65), Rel-B, c-Rel, p50 (cleavage product of NF- $\kappa \mathrm{B} 1 / \mathrm{p} 105$ ), and p52 (cleavage prod- 
uct of NF- $\kappa \mathrm{B} 2 / \mathrm{p} 100)$. In most systems NF- $\kappa \mathrm{B}$ exists in an inactive form by associating with an inhibitory protein of $\mathrm{I} \kappa \mathrm{B}$ family (I $\kappa \mathrm{B}-\alpha, \mathrm{I} \kappa \mathrm{B}-\beta, \mathrm{I} \kappa \mathrm{B}-\epsilon, \mathrm{I} \kappa \mathrm{B}-\gamma$, and $\mathrm{Bcl}-3)$. This association sequesters NF- $\kappa \mathrm{B}$ in the cytoplasm. Activation of NF- $\kappa \mathrm{B}$ usually is achieved via phosphorylation of $\mathrm{I} \kappa \mathrm{B}$, followed by its degradation via a ubiquitin-proteasome-mediated degradation pathway. However, cleavage of $\mathrm{I} \kappa \mathrm{B}$ by the protease calpain also has been suggested as an alternative pathway to $\mathrm{I} \kappa \mathrm{B}$ degradation (Miyamoto et al., 1998; Pianetti et al., 2001). Degradation of I $\kappa$ B allows NF- $\kappa \mathrm{B}$ to translocate to the nucleus, where it binds to the $\kappa \mathrm{B}$ consensus sequence and modulates numerous target genes.

Several studies have shown that NF- $\kappa \mathrm{B}$ is activated in response to in vitro and/or in vivo insults such as stroke (Clemens et al., 1997; Schneider et al., 1999), kainate-induced seizures (Nakai et al., 2000), and $\beta$-amyloid treatment of fetal rat cortical neurons (Bales et al., 1998). However, the functional role of Rel/NF- $\kappa$ B in neuronal death/survival has been a matter of debate (for review, see Barkett and Gilmore, 1999), and both pro-apoptotic and antiapoptotic roles have been ascribed to NF- $\kappa \mathrm{B}$ activation (Wang et al., 1996; Lin et al., 1998). In this regard, NF- $\kappa \mathrm{B}$ can activate death genes (e.g., p53, c-myc, Fas) (Cheema et al., 1999; Qin et al., 1999) as well as pro-survival genes [inhibitors of apoptosis (IAPs), Bcl-2 and Bcl-x, and antioxidant enzymes such as manganese superoxide dismutase (MnSOD)] (Mattson et al., 1997; LaCasse et al., 1998). The mechanisms underlying the dual nature of NF- $\kappa \mathrm{B}$ is not well understood.

Presently, we show that DNA damage initiated by camptothecin activates the NF- $\kappa \mathrm{B}$ pathway. Interestingly, it does so in a manner that is independent of the previously established CDK and 553 pathways. Most importantly, we find that the functional role of NF- $\kappa \mathrm{B}$ is dependent on the timing and manner by which the NF- $\kappa \mathrm{B}$ signal is manipulated. Acute inhibition of NF- $\kappa \mathrm{B}$ delays death by the inhibition of $\mathrm{p} 53$ induction. More chronic $\mathrm{NF}-\kappa \mathrm{B}$ inhibition, however, leads to neuronal death. Therefore, even in the same cell type NF- $\kappa \mathrm{B}$ can be manipulated to display multiple effects. These findings provide a plausible explanation for the dual role of NF- $\kappa \mathrm{B}$ in survival and death.

\section{Materials and Methods}

Material. Flavopiridol [L86-8275 \{(-)cis-5,7-dihydroxy-2-(2-chlorophenyl)-8[4-(3-hydroxy-1-methyl)-piperidinyl]-4H-benzopyran-4-one $\}]$ was a generous gift from Dr. Peter J. Worland (National Cancer Institute, Bethesda, MD). Camptothecin was obtained from Sigma (St. Louis, MO). BAY 11-7082, CAPE (caffeic acid phenethlester), and helenalin were purchased from Biomol (Plymouth Meeting, PA); ALLN was obtained from Calbiochem (San Diego, CA). Recombinant mouse tumor necrosis factor- $\alpha$ (TNF- $\alpha$ ) was purchased from Invitrogen (San Diego, CA).

Knock-out mice. p50, p65, and ataxia telangiectasia-mutated (ATM) heterozygous breeding pairs were obtained from Jackson Laboratories (Bar Harbor, ME) on a mixed C57BL/6 × 129 background. p53-deficient animals were on a C57BL/6J background. All knock-out neurons were obtained from embryos derived from heterozygous breeding. The p65 genotyping protocol was performed by using $5^{\prime}$-CCTATAGAGGAGCAGCGCGGG-3' (p65 5'), 5' -AATCGGATGTGAGAGGACAGG-3' (p65 $3^{\prime}$ ), and 5'-AAATGTGTCAGTTTCATAGCCTGAAGAACG-3' (HH-neo) primers to amplify wild type (130 bp) or NeoTD inserted, knocked out, p65 alleles $(160 \mathrm{bp})$. PCR condition was $94^{\circ} \mathrm{C}$ for $5 \mathrm{~min}(1 \mathrm{cycle}), 94^{\circ} \mathrm{C}$ for $1 \mathrm{~min}$, $65^{\circ} \mathrm{C}$ for $1.5 \mathrm{~min}$, and $72^{\circ} \mathrm{C}$ for $1 \mathrm{~min}(30$ cycles). p65 deficiency was confirmed further by performing an additional Western blot analysis on embryonic liver tissue protein extract, using anti-p65 specific antibody (sc-109, Santa Cruz, Santa Cruz, CA). p50 genotyping was performed by a PCR reaction that included the following protocol: $94^{\circ} \mathrm{C}$ for $1.5 \mathrm{~min}(1 \mathrm{cycle})$, $94^{\circ} \mathrm{C}$ for $20 \mathrm{sec}, 60^{\circ} \mathrm{C}$ for $30 \mathrm{sec}\left(-0.5^{\circ} \mathrm{C}\right.$ per cycle), $72^{\circ} \mathrm{C}$ for $35 \mathrm{sec}(12$ cycles $)$, $94^{\circ} \mathrm{C}$ for $20 \mathrm{sec}, 55^{\circ} \mathrm{C}$ for $30 \mathrm{sec}, 72^{\circ} \mathrm{C}$ for $35 \mathrm{sec}(25 \mathrm{cycles})$, and $72^{\circ} \mathrm{C}$ for 2 min, and by using $5^{\prime}$-GCAAACCTGGGAATACTTCATGTGACTAAG-3'
(IMR 476, NF- $\kappa$ b1 wild type), 5'-ATAGGCAAGGTCAGAATGCACCAGAAGTCC-3' (IMR 477, NF- $\kappa$ b1 wild type), and 5'-AAATGTGTCAGTTTCATAGCCTGAAGAACG-3' (IMR 478, NF- $\kappa$ b1 knock-out) to detect wild-type (100 bp) or knock-out (190 bp) alleles. p53-deficient genotyping of each individual embryo was performed by using $5^{\prime}$ GTATCTGGAAGACAGGCAGAC-3' (O-p53-1) and 5' -TGTACTTGTAGTGGATGGTGG-3' (O-p53-2) primers to detect the wild-type allele (450 bp) and 5' -TATACTCAGAGCCGGCCT-3' (O-p53-X7) and $5^{\prime}$-TTCCTCGTGCTTTACGGTATC-3' (O-neo-2) primers to detect the targeted allele (533 bp). PCR conditions included $94^{\circ} \mathrm{C}$ for $5 \mathrm{~min}(1 \mathrm{cycle}), 94^{\circ} \mathrm{C}$ for $1 \mathrm{~min}, 55^{\circ} \mathrm{C}$ for $1 \mathrm{~min}, 72^{\circ} \mathrm{C}$ for $1 \mathrm{~min}(30$ cycles), and $72^{\circ} \mathrm{C}$ for $10 \mathrm{~min}$. ATM was genotyped as follows: 5' -GCTGCCATACTTGATCCATG-3' (IMR 640, ATM wild type), 5' TCCGAATTTGCAGGAGTTG-3' (IMR 641, ATM wild type), 5'-CTTGGGTGGAGAGGCTATTC-3' (IMR013, Neol generic neo primer), and 5'-AGGTGAGATGACAGGAGATC-3' (IMR014, Neo2 generic neo primer). These were used as primers to amplify wild-type (147 bp) and knock-out $\left(280 \mathrm{bp}\right.$ ) alleles in a PCR protocol that included $94^{\circ} \mathrm{C}$ for $3 \mathrm{~min}(1$ cycle), $94^{\circ} \mathrm{C}$ for $20 \mathrm{sec}, 64^{\circ} \mathrm{C}$ for $30 \mathrm{sec}\left(-0.5^{\circ} \mathrm{C}\right.$ per cycle $), 72^{\circ} \mathrm{C}$ for $35 \mathrm{sec}(12$ cycles), $94^{\circ} \mathrm{C}$ for $20 \mathrm{sec} 58^{\circ} \mathrm{C}$ for $30 \mathrm{sec}, 72^{\circ} \mathrm{C}$ for $35 \mathrm{sec}(25 \mathrm{cycles})$, and $72^{\circ} \mathrm{C}$ for $2 \mathrm{~min}$.

Cell culture. Cortical neurons were cultured from $14.5 \mathrm{~d}$ mouse embryos (CD1, Charles River, Wilmington, MA or from knock-out breeding as described above) as described previously (Giovanni et al., 2000). Briefly, neurons were plated into 24 -well dishes $(\sim 300,000$ cells/well) or six-well dishes (1-3 million cells/well) coated with poly-D-lysine (100 $\mu \mathrm{g} / \mathrm{ml})$ in serum-free medium [MEM/F12 (1:1) supplemented with 6 $\mathrm{mg} / \mathrm{ml}$ D-glucose, $100 \mu \mathrm{g} / \mathrm{ml}$ transferrin, $25 \mu \mathrm{g} / \mathrm{ml}$ insulin, 20 nM progesterone, $60 \mu \mathrm{M}$ putrescine, $30 \mathrm{~nm}$ selenium]. At 1-2 d after initial plating the plated cells were treated with serum-free medium supplemented with camptothecin $(10 \mu \mathrm{M})$, flavopiridol $(1 \mu \mathrm{M})$, or NF- $\kappa$ B inhibitors as indicated in this text and figures. At appropriate times of culture under the conditions described in this text the cells were lysed, and the numbers of viable cells were evaluated. Briefly, the cells were lysed in $200 \mu \mathrm{l}$ of cell lysis buffer $(0.1 \times \mathrm{PBS}, \mathrm{pH} 7.4$, containing $0.5 \%$ Triton X-100, $2 \mathrm{~mm}$ $\mathrm{MgCl}_{2}$, and $0.5 \mathrm{gm} / 100 \mathrm{ml}$ ethylhexadecyldimethylammonium bromide), which disrupts cells but leaves the nuclei intact. Then $10 \mu \mathrm{l}$ of sample from each culture was loaded onto a hemacytometer, and the number of healthy, intact nuclei was evaluated by phase microscopy. To obtain a positive control for I $\kappa$ B phosphorylation, we cultured NIH-3T3 fibroblasts cells in six-well culture dishes in DMEM with $10 \%$ fetal calf serum (FCS) and allowed them to proliferate until they were $70-80 \%$ confluent. The fibroblasts were treated with $10 \mathrm{ng} / \mathrm{ml} \mathrm{recombinant} \mathrm{mu-}$ rine TNF- $\alpha$ (Invitrogen) for the indicated times.

RNA interference transfection. To suppress the expression of the p65 subunit of NF- $\kappa \mathrm{B}$, we designed a double-stranded short-interfering RNA (siRNA) to p65 (sequence, AAGAAGCACAGAUACCACCAA). The siRNA duplex along with a nonspecific control duplex (GCGCGCUUUGUAGGAUUCG) was obtained from Dharmacon (Lafayette, CO) RNA interference (RNAi) technology in the $2^{\prime}$-deprotected and desalted form. Brain cortical tissues were dissected from the brains of CD-1 mouse embryos, 14-15 d of embryonic life, as previously described by Fortin et al. (2001). At $48 \mathrm{hr}$ after plating the cells were transfected by RNAi with GeneSilencer siRNA transfection reagent (Gene Therapy System, San Diego, CA), following the instruction manual provided by the supplier. Briefly, GeneSilencer reagent and siRNA were diluted in serum-free medium (Opti-MEM, Invitrogen) separately in appropriate amounts and mixed and incubated at room temperature for $10 \mathrm{~min}$ to allow the siRNA/lipid complex to form. Then $60 \mathrm{pmol} /$ well of siRNA in 24-well plates was used. Alternatively, we used Lipofectamine 2000 (Invitrogen, Carlsbad, CA) instead of GeneSilencer reagent, and allowed 20 min room temperature incubation for siRNA/lipid complex formation.

Semiquantitative RT-PCR analysis. Total RNA was isolated from cells via Tripure isolation reagent according to the manufacturer's instructions (Boehringer Mannheim, Indianapolis, IN). Total RNA (2 ng) was used for cDNA synthesis and targeted gene amplification via the SuperScript One-Step RT-PCR kit (Invitrogen). cDNA synthesis was performed at $48^{\circ} \mathrm{C}$ for $45 \mathrm{~min}$, followed by a $2 \mathrm{~min}$ initial denaturation step at $94^{\circ} \mathrm{C}$. To amplify PUMA, we used $5^{\prime}$-CCTCAGCCCTCCCTGTCA- 
CCAG-3' (PUMA forward) and 5' -CCGCCGCTCGTACTGCGCGTTG-3' (PUMA reverse) in $25 \mathrm{cycles}$ of $94^{\circ} \mathrm{C}$ for $30 \mathrm{sec}, 55^{\circ} \mathrm{C}$ for $30 \mathrm{sec}$, and $72^{\circ} \mathrm{C}$ for $30 \mathrm{sec}$. NOXA primers, $5^{\prime}$-CAACGCGGGCAGAGCTACCACCTGA (NOXA forward) and 5'-TGGGCTTGGGCTCCTCATCCTGCTC-3' (NOXA reverse), were used in $34 \mathrm{cycles}$ of $94^{\circ} \mathrm{C}$ for $30 \mathrm{sec}, 59^{\circ} \mathrm{C}$ for $30 \mathrm{sec}$, and $72^{\circ} \mathrm{C}$ for $1 \mathrm{~min}$ of thermal cycling. p53 levels were determined by using mouse-specific primers: p53 forward, $5^{\prime}$-AGTGGATCCTTTATTCTACCCTTTCCTATAAGCCATA-3', and p53 reverse, 5' -AGTGGTACCTTAGTTCCTGATTTCCTTCCATTTTTTG-3'. Total RNA (50 ng) was used for cDNA synthesis and targeted gene amplification. cDNA synthesis was performed at $45^{\circ} \mathrm{C}$ for $45 \mathrm{~min}$, followed by a $2 \mathrm{~min}$ initial denaturation step at $94^{\circ} \mathrm{C}$. This was followed by 37 cycles (p53) at $94^{\circ} \mathrm{C}$ for $30 \mathrm{sec}, 56^{\circ} \mathrm{C}$ for $30 \mathrm{sec}$, and $72^{\circ} \mathrm{C}$ for $1 \mathrm{~min}$. The resulting product was sequenced and confirmed to be p53. We used ribosomal protein S12 mRNA as a loading control (Kenmochi et al., 1998). S12 cDNA was amplified by $5^{\prime}$-GGAAGGCATAGCTGCTGG- $3^{\prime}$ and $5^{\prime}$-CCTCGATGACATCCTTGG- $3^{\prime}$ as primers in 25 cycles of $94^{\circ} \mathrm{C}$ for $30 \mathrm{sec}, 57^{\circ} \mathrm{C}$ for $30 \mathrm{sec}$, and $72^{\circ} \mathrm{C}$ for $1 \mathrm{~min}$ of PCR reaction.

Electromobility shift assay. Cortical neurons (embryonic day 14.5) were harvested at the indicated times and lysed in a solution containing (in mM) 10 HEPES buffer, pH 7.9, $10 \mathrm{KCl}, 1.5 \mathrm{MgCl}_{2}, 0.5$ DTT, 0.5 PMSF plus $0.1 \% \mathrm{NP}-40$ for $20 \mathrm{~min}$ on ice to obtain cytoplasmic proteins. After centrifugation $(12,000 \mathrm{rpm}, 5 \mathrm{~min})$ the pellet was resuspended in buffer containing (in mM) 20 HEPES, pH 7.9, $420 \mathrm{NaCl}, 1.5 \mathrm{MgCl}_{2}, 0.2$ EDTA, 0.5 DTT, 0.5 PMSF, 0.15 spermin, plus $25 \%$ glycerol, $5 \mu \mathrm{g} / \mathrm{ml}$ aprotinin, $5 \mu \mathrm{g} / \mathrm{ml}$ leupeptin, and $5 \mu \mathrm{g} / \mathrm{ml}$ pepstatin. After incubation for $45 \mathrm{~min}$ the extract was centrifuged (14,000 rpm, $10 \mathrm{~min})$ to precipitate debris and was measured for protein by Bradford assay (Bio-Rad, Hercules, CA). NF- $\kappa \mathrm{B}$ probe was prepared by incubating 20 ng of double-stranded $\kappa \mathrm{B}$ consensus oligonucleotides ( $5^{\prime}$-AGTTGAGGGGACTTTCCCAGGC- ${ }^{\prime}$ ) in a reaction mixture containing T4 poly nucleotide kinase (T4 PNK), $1 \times$ reaction buffer (T4 PNK and $10 \times$ reaction buffer obtained from New England Biolabs, Beverly, MA), and $60 \mu \mathrm{Ci}$ of $\gamma^{32} \mathrm{P}$-dATP (Amersham, Arlington Heights, IL) in $37^{\circ} \mathrm{C}$ for $1 \mathrm{hr}$. The reaction was purified through a Sephadex G-25 spin column, and the end product was diluted in $200 \mu$ l of dilution buffer containing (in mM) 20 HEPES, pH 7.9, 0.5 EDTA, 0.5 EGTA, $100 \mathrm{KCl}$, $0.5 \mathrm{DTT}$, and $10 \%$ glycerol. Then $5 \mu \mathrm{g}$ of nuclear protein extract samples was incubated with DNA binding buffer containing (in mM) 20 HEPES, pH 7.9, $0.2 \mathrm{EDTA}, 0.2 \mathrm{EGTA}, 100 \mathrm{KCl}$, and 2 DTT plus $50 \%$ glycerol along with $5 \mu \mathrm{g}$ of poly(dI-dC) (Roche Diagnostics, Laval, Quebec, Canada) and $0.2 \mathrm{ng}$ of 5 -end-labeled NF- $\kappa$ B consensus double-stranded DNA probe $(100,000$ cpm) labeled with $\gamma^{32} \mathrm{P}$-dATP (Amersham, Arlington Heights, IL). For cold competition 125-fold excess ( $25 \mathrm{ng}$ ) of unlabeled probe was added before labeled probe, and the same amount of unlabeled mutant double-stranded oligonucleotide (with a " $G$ " $\rightarrow$ " $C$ " substitution in the underlined position in the above-mentioned consensus $\kappa \mathrm{B}$ sequence) was added to check the specificity of the $\kappa \mathrm{B}$-specific band. For supershift assays anti-p65 (Santa Cruz sc-109 X), anti-p50 (Santa Cruz sc-1190 X), anti-Rel-B (Santa Cruz sc-226 X), anti-c-Rel (Santa Cruz sc-71 X), or anti-p52 (Santa Cruz sc-298 X) antibody was added to the reaction mixture and incubated for $30 \mathrm{~min}$. Samples were resolved on $5 \%$ nondenaturing polyacrylamide gel and visualized by autoradiography.

I $\mathrm{B}$ adenoviral vector. Recombinant adenoviral vectors were constructed by using the Cre-lox system as described previously (Hardy et al., 1997). Briefly, I $\kappa$ B containing Ser ${ }^{32}$ and Ser ${ }^{36}$-to-alanine mutations was excised from pcDNA3(+) (Invitrogen), using HindIII and NotI. The sequence encoding enhanced green fluorescent protein (EGFP) was excised from pEGFP-C3 (BD Biosciences Clontech, Palo Alto, CA), using NheI and HindIII. Both fragments were ligated into pAdlox to produce pAdlox-EGFP-C3-I $\kappa \mathrm{B}-\alpha$. Purified plasmids were cotransfected onto HEK293 CRE cells along with $\Psi 5$ viral backbone DNA, using standard calcium phosphate techniques. Crude lysate was obtained via three successive rounds of freeze-thaw, and recombination was confirmed by restriction digest of the viral DNA. The crude lysate was purified by plaque isolation and amplified to high titer. Then the recombinant adenovirus was purified and concentrated via two rounds on cesium chloride gradients; concentration was determined by plaque assay.

SDS-PAGE and immunoblot analysis. After we treated the cells for the desired time course, the medium was aspirated and the cells were washed twice with cold PBS. Cells were harvested by scraping in SDS sample buffer (containing $62.5 \mathrm{~mm}$ Tris- $\mathrm{HCl}, 2 \%$ w/v SDS, $10 \%$ glycerol, $50 \mathrm{~mm}$ dithiothrietol, and $0.01 \% \mathrm{w} / \mathrm{v}$ bromophenol blue) and were transferred to a microcentrifuge tube. After a brief sonication $(10-15 \mathrm{sec})$ the samples were heated to $95-100^{\circ} \mathrm{C}$ for $5 \mathrm{~min}$. Samples were resolved on $10-$ $12 \%$ SDS-PAGE and transferred to nitrocellulose membranes (Bio-Rad). Membranes were incubated with primary antibodies diluted in 3\%BSA and secondary antibodies diluted in 5\% milk in TBS/T (Tris-buffered saline plus Tween 20) containing $50 \mathrm{~mm}$ Tris, $\mathrm{pH}$ 7.4, $150 \mathrm{~mm} \mathrm{NaCl}$, and $0.1 \% \mathrm{v} / \mathrm{v}$ Tween 20 . Primary antibodies and their dilution were as follows: anti-p65 (1:1000; Santa Cruz), I $\kappa$ B- $\alpha$ (1:1000; Santa Cruz), phospho-I $\kappa$ B- $\alpha$ (Ser ${ }^{32}, 1: 500$; Cell Signaling Technology, Beverly, MA), $\beta$-actin (1:3000; Sigma), I $\kappa$ B- $\beta$ (sc-945, 1:1000; Santa Cruz), and p53 (1:2000; 1C12 monoclonal, Cell Signaling Technology). Goat antimouse or anti-rabbit IgG(H+L) HRP conjugate (Bio-Rad) were used as secondary antibodies at 1:3000 dilution. Immunoreactivity was detected by using the Western blot chemiluminescence reagent system (PerkinElmer, Boston, MA). Films were exposed at different time points to ensure the optimum density, but not saturated.

Transient transfection and immunostaining. At $24-36 \mathrm{hr}$ after initial plating the cortical neurons were transiently transfected by the calcium phosphate coprecipitation protocol as described previously (Xia et al., 1996). The neurons were cotransfected with a CMV promoter-driven expression plasmid, expressing lacZ or GFP $(2 \mu \mathrm{g})$ and an empty pcDNA3 vector (Invitrogen) or lacZ/GFP and $\mathrm{I} \kappa \mathrm{B}$ super-repressor (I $\kappa$ BSR; $4 \mu \mathrm{g}$ ). DNA damage was induced $16 \mathrm{hr}$ after transfection by adding camptothecin $(10 \mu \mathrm{M})$ for $14 \mathrm{hr}$ or as indicated in the text or figures. Cells were fixed with a paraformaldehyde-based fixative solution (4\% paraformaldehyde, $125 \mathrm{~mm}$ sodium dihydrogen phosphate, $125 \mathrm{~mm}$ disodium hydrogen phosphate, $14 \%$ picric acid) for $30 \mathrm{~min}$ at room temperature and washed with PBS three times. When cotransfected with LacZ reporter, the neurons then were incubated with anti- $\beta$ galactosidase antibody ( $\beta$-gal; Promega) for $12-14 \mathrm{hr}$ at $4^{\circ} \mathrm{C}$, followed by Cy3-conjugated secondary antibody incubation ( $1 \mathrm{hr}$, room temperature) with subsequent PBS wash after each step (three times at room temperature). The transfected cells were identified by $\mathrm{Cy} 3$ fluorescence indicating $\beta$-gal expression. The integrity of the nucleus was analyzed by nuclear staining with Hoechst 33342 (for $10 \mathrm{~min}$ at room temperature; Sigma). The live cells were scored on the basis of the expression of $\beta$-gal/ GFP and their nuclear integrity. The percentage of survival was calculated as the percentage of live neurons (in $\beta$-gal/GFP-positive cells) over the total number of neurons expressing the reporter gene and presented as the mean \pm SE of three independent experiments $(n=3)$.

Adenoviral infection. Cortical neurons were exposed to recombinant adenovirus expressing GFP or GFP-tagged I $\kappa$ BSR, lacZ, or p53 at the time of plating. At $\sim 16 \mathrm{hr}$ after infection the cultures were exposed to camptothecin as described above and assessed for neuronal survival.

Immunofluorescence for p53. Cortical neurons were cultured and infected with adenovirus expressing both GFP and I $\kappa$ BSR as described above. After fixation with previously described fixative solution for 30 $\mathrm{min}$ at room temperature, the cells were washed three times with PBS and incubated with anti-p53 (1:2000; 1C12 monoclonal, Cell Signaling Technology) overnight. After being washed, Cy3-linked (1:300; Jackson Laboratories) secondary antibodies were added for $1 \mathrm{hr}$. Nuclei were stained with Hoechst dye 33342 (Sigma). Cells were visualized under fluorescent microscopy, and GFP-expressing cells were evaluated for p53 in each group. GFP-producing cells, which showed p53 induction, were scored as "positive" versus "negative" cells that expressed GFP but showed little or no nuclear p53 immunoreactivity.

\section{Results}

\section{NF- $\kappa$ B activation/regulation after camptothecin treatment}

To determine the involvement of the NF- $\kappa$ B pathway in neuronal death/survival after DNA damage, we first examined the DNA binding activity of NF- $\kappa \mathrm{B}$ after camptothecin exposure of embryonic cortical neurons by electrophoretic mobility shift assay (EMSA). Nuclear protein extracts, obtained from neuronal cultures treated with camptothecin for $0-8 \mathrm{hr}$, were incubated with 


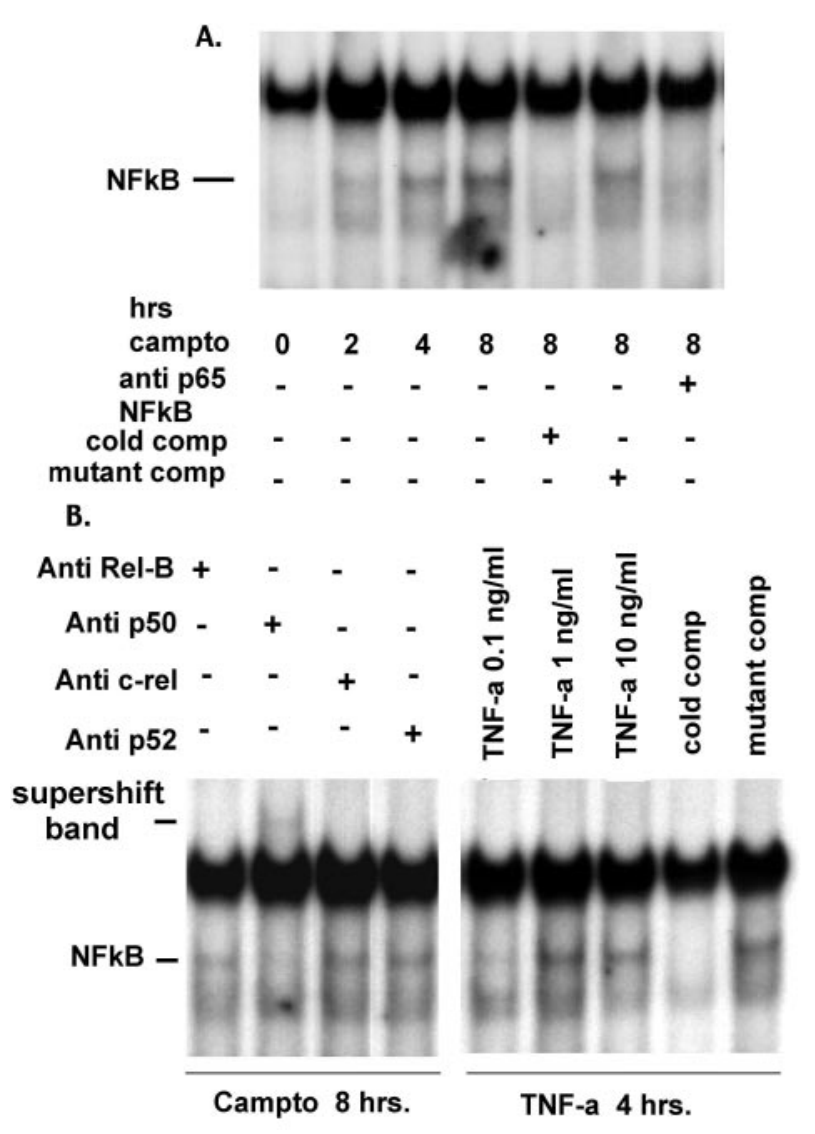

Figure 1. Camptothecin treatment induces NF- $\kappa \mathrm{B} D \mathrm{DNA}$ binding. Nuclear protein extracts of cultured cortical neurons subject to camptothecin for the indicated times were subjected to EMSA. A, NF- $\kappa$ B-related band appeared as early as $2 \mathrm{hr}$ and reached its maximum intensity at $\sim 8 \mathrm{hr}$. The induced band was reactive with the antibody to NF- $\kappa B$ family member $p 65$. $B$, The camptothecin-induced NF- $\kappa B$ band was also reactive to the antibody to $p 50$, but not Rel-B, c-Rel, or p52. TNF- $\alpha$-treated cortical neurons also were included as a positive control. Cold comp refers to the addition of 125 -fold of excess amounts of unlabeled probe. Mutant comp refers to the addition of a mutant form of the NF- $\kappa \mathrm{B}$-specific probe that is unable to compete with the consensus radiolabeled probe.

radiolabeled consensus NF- $\kappa$ B oligonucleotide under nondenaturing conditions. As shown in Figure 1, a major band appeared as early as $2 \mathrm{hr}$ after camptothecin treatment and gradually increased throughout the $8 \mathrm{hr}$ time course. This band appeared to be specific for NF- $\kappa$ B DNA binding because the addition of excess unlabeled consensus probe abolished the signal, whereas the addition of mutant competitor probe had no effect. In addition, it had the same mobility as a positive control for NF- $\kappa \mathrm{B}$ induced by TNF- $\alpha$ treatment. To determine the composition of this band, we performed supershift experiments. Anti-p65 antibody resulted in loss of the induced complex, whereas anti-p50 antibody caused a supershift of the mentioned band. Antibodies to Rel-B, p52, or $c$-Rel had no effect. This indicates that the active form of NF- $\kappa \mathrm{B}$ induced by DNA damage and detected by EMSA is composed of p65 and p50.

We next examined the mechanism by which NF- $\kappa \mathrm{B}$ may be activated after DNA damage. NF- $\kappa \mathrm{B}$ is known to be regulated via binding to $\mathrm{I} \kappa \mathrm{B}$. Accordingly, we examined for $\mathrm{I} \kappa \mathrm{B}$ levels by Western blot analyses. Consistent with increased NF- $\kappa$ B DNA binding observed by EMSA, we detected a decrease in the level of $\mathrm{I} \kappa \mathrm{B}-\alpha$ after camptothecin treatment (Fig. 2A). Densitometric analysis, standardized against $\beta$-actin, indicates that $\mathrm{I} \kappa \mathrm{B}-\alpha$ degradation begins as early as $2 \mathrm{hr}$ from the start of camptothecin exposure.
A.
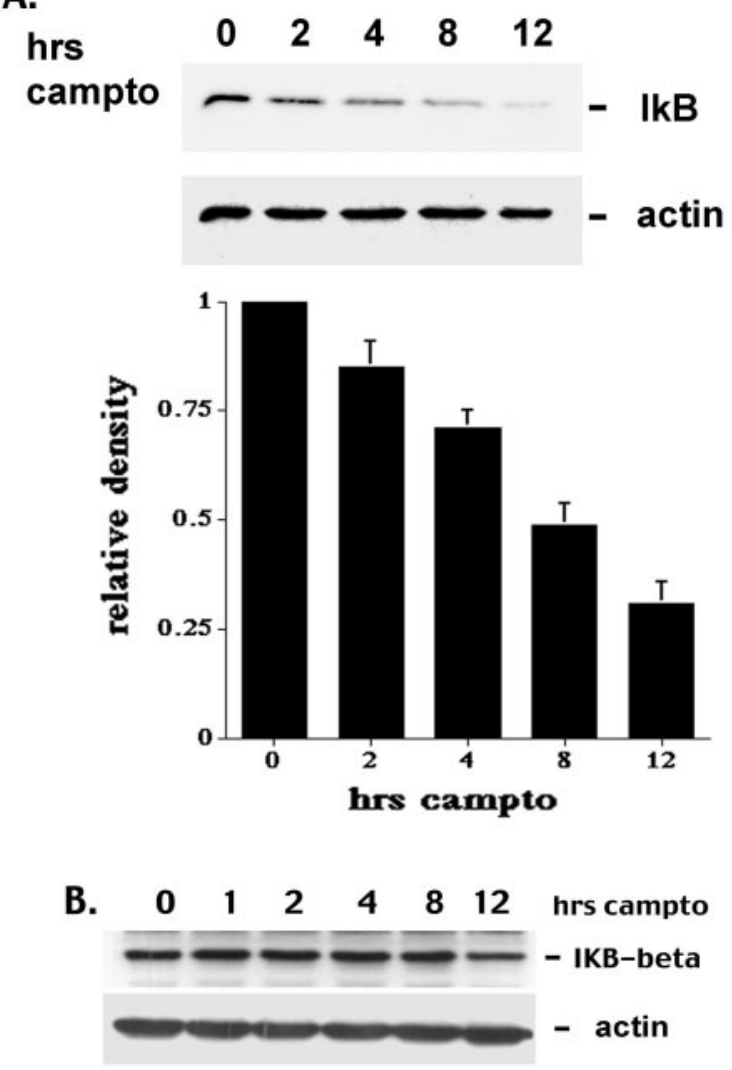

Figure 2. Camptothecin-induced activation of NF- $\kappa B$ is accompanied by $\left.\right|_{\kappa} B$ degradation. $A$, Total cell lysates of cultured cortical neurons at indicated times were analyzed for $\mid \kappa B-\alpha$ by Western blot analysis. Densitometric analysis of $I_{\kappa} B$ degradation from three independent experiments is provided. All data are normalized to loading controls. Error bars are represented as \pm SEM. $B$, Western blot analyses of cortical neurons for $I_{\kappa} B-\beta$ levels after camptothecin treatment.

We also examined for $\mathrm{I} \kappa \mathrm{B}-\beta$ degradation, another important member of the $\mathrm{I} \kappa \mathrm{B}$ family. In contrast to $\mathrm{I} \kappa \mathrm{B}-\alpha, \mathrm{I} \kappa \mathrm{B}-\beta$ levels remained constant until the $12 \mathrm{hr}$ time point (Fig. $2 \mathrm{~B}$ ).

One mechanism of control over $\mathrm{I} \kappa \mathrm{B}$ stability is via phosphorylation at $\operatorname{Ser}^{32}$ and $\operatorname{Ser}^{36}$ (Karin, 1999). Interestingly, however, no consistent increase in $\mathrm{I} \kappa \mathrm{B}-\alpha$ phosphorylation was observed at similar time points with a phospho-I $\kappa \mathrm{B}\left(\mathrm{Ser}^{32}\right)$ specific antibody (Fig. 3B). To ensure that the antibody is able to detect the phosphorylated form of $\mathrm{I} \kappa \mathrm{B}$, we performed a control experiment by treatment of fibroblasts with TNF- $\alpha$. As is shown in Figure $3 A$, the antibody effectively recognizes phospho- $\mathrm{I} \kappa \mathrm{B}$ in this classical paradigm of cytokine-induced NF- $\kappa \mathrm{B}$ activation. Because the phosphorylated form of $\mathrm{I} \kappa \mathrm{B}$ is ubiquitinated rapidly and degraded by proteasomal activity, we also treated neurons in the presence of camptothecin and a proteasomal inhibitor ALLN (50 $\mu \mathrm{M})$ and assessed for phospho-I $\kappa \mathrm{B}\left(\mathrm{Ser}^{32}\right)$. Similar to camptothecin treatment alone, no increase in phospho- $\mathrm{I} \kappa \mathrm{B}$ was detected (Fig. 3C). Taken together, these observations strongly suggest the $\mathrm{NF}-\kappa \mathrm{B}$ signaling is activated after DNA damage and that this activation may occur via a mechanism other than phosphorylation of $\mathrm{I} \kappa \mathrm{B}$ on $\mathrm{Ser}^{32}$. We also examined several potential upstream regulators of NF- $\kappa$ B. ATM, a PI3-kinase like family member that is thought to regulate p53 stability under select conditions of DNA damage (Keramaris et al., 2003), also is reported to regulate NF- $\kappa$ B activity (Piret et al., 1999). However, ATM-deficient neurons show no defect in NF- $\kappa$ B activation, as 
A.

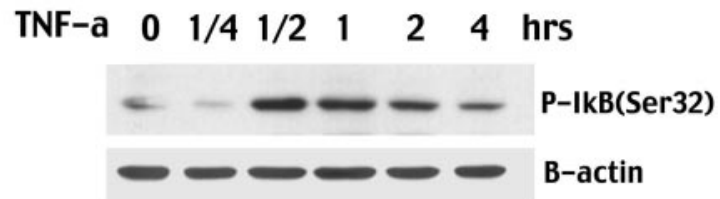

B.
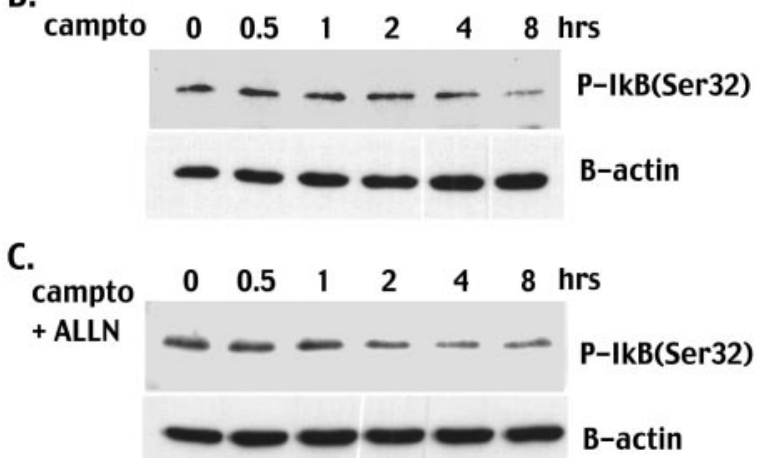

Figure 3. Lack of increase in $\mid \kappa B-\alpha$ phosphorylation in cortical neurons after DNA damage. $A$, Positive control for Ser ${ }^{32}$ phosphorylation; fibroblasts were treated with TNF (10 $\left.\mu \mathrm{m}\right)$ for the indicated times and analyzed by Western blot analyses, using a phospho-epitope-specific $I_{\kappa} \mathrm{B}-\alpha$ antibody. Total cell lysates of cultured cortical neurons also were treated with camptothecin alone $(B)$ or camptothecin and the proteasomal inhibitor ALLN $(C ; 50 \mu \mathrm{m})$ for the indicated times and analyzed for $\operatorname{Ser}^{32} I_{\kappa} B-\alpha$ phosphorylation as above.

detected by EMSA, after camptothecin treatment (data not shown). Similarly, p53-deficient neurons still induced NF- $\kappa$ B activation (data not shown). Finally, previous reports have suggested a functional link between the CDK/Rb pathway, a critical death effector in neurons after DNA damage, and NF- $\kappa \mathrm{B}$ (Joyce et al., 2001). However, treatment with the general CDK inhibitor flavopiridol had no effect on NF- $\kappa \mathrm{B}$ DNA binding and $\mathrm{I} \kappa \mathrm{B}-\alpha$ degradation after camptothecin treatment (data not shown). Taken together, these data indicate that IKK, ATM, p53, and CDKs do not regulate NF- $\kappa \mathrm{B}$ activation.

\section{Dual functional role of NF- $\boldsymbol{\kappa} B$}

We next examined whether the inhibition of NF- $\kappa$ B affects DNA damage-induced cell death. In this regard we first used pharmaceutical agents that inhibit NF- $\kappa \mathrm{B}$ via different mechanisms. Helenalin inhibits NF- $\kappa$ B by specific and irreversible alkylation of the p65 subunit, thereby blocking DNA binding (Lyss et al., 1998). Parallel analyses of helenalin effects on neuronal death either on its own or in combination with camptothecin indicated that helenalin significantly protected against camptothecin-induced neuronal death as evaluated by nuclear morphology. In this case, considerable neurite loss was observed along with the protection (Fig. $4 A, B)$. However, prolonged exposure to helenalin alone (48 hr or more, without camptothecin exposure) induced death. Similar findings were observed with another NF- $\kappa \mathrm{B}$ inhibitor, CAPE (Natarajan et al., 1996), which inhibits nuclear translocation of NF- $\kappa \mathrm{B}$ (data not shown). Interestingly, the IKK inhibitor BAY 11-7082 (Pierce et al., 1997) failed to be protective at any dose that was examined and, similar to the other NF- $\kappa$ B inhibitors, showed toxicity (Fig. 4C). This result is consistent with the lack of increased $\mathrm{I} \kappa \mathrm{B}$ phosphorylation with camptothecin exposure. Taken together, these findings suggest that, although a basal activity of NF- $\kappa \mathrm{B}$ is needed for neuronal survival and neurite
A
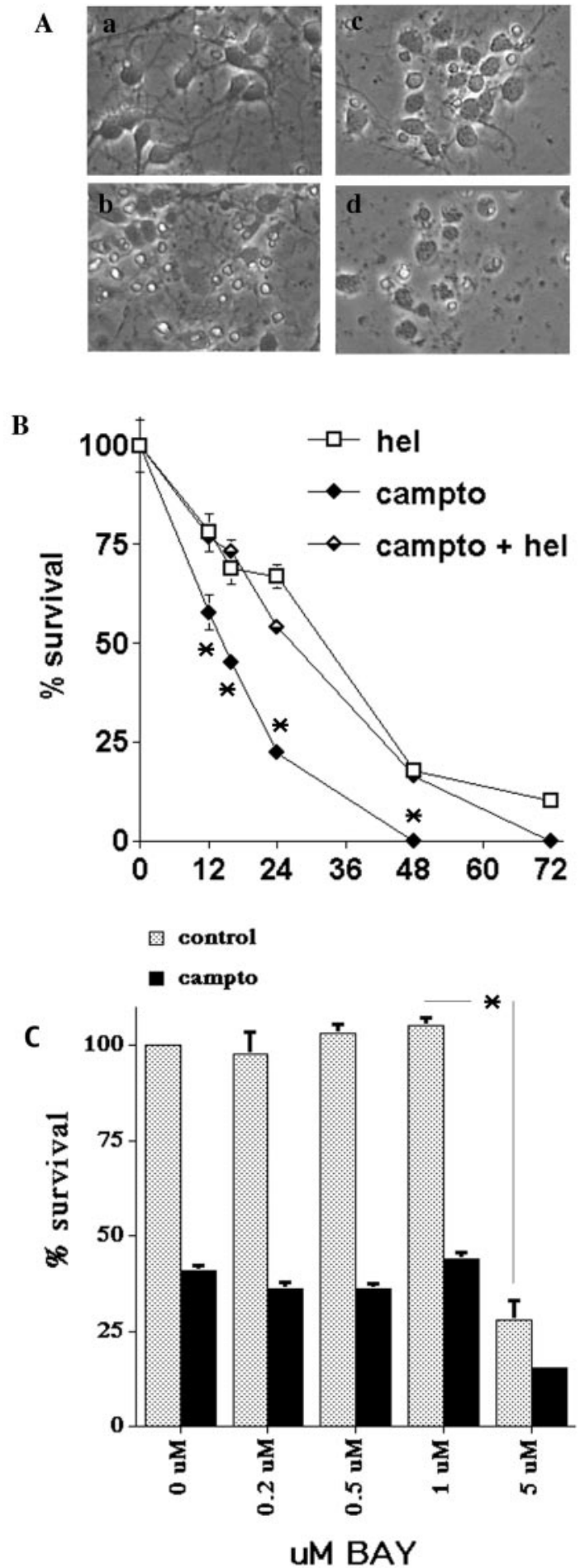

Figure 4. Effects of pharmacological inhibitors of the NF- $\kappa$ B pathway. Cultured cortical neurons were cotreated with camptothecin $(10 \mu \mathrm{m})$ and the indicated concentrations of the p65 inhibitor helenalin (hel) or the IKK inhibitor BAY 11-7082. A, Phase-contrast photomicrographs of neuronal cultures untreated $(a)$, treated with camptothecin $(b)$, and cotreated with 5 $\mu \mathrm{M}(c)$ or $10 \mu \mathrm{M}(d)$ helenalin for $12 \mathrm{hr}$. B, Quantitation of neuronal survival with helenalin (2.5 $\mu \mathrm{m})$ as assessed by nuclear counts under the conditions as indicated. Similar results were obtained for $5 \mu \mathrm{m}$ helenalin; however, the time course of toxicity was accelerated. Each data point is the mean \pm SEM from three independent cultures. ${ }^{*} p<0.05$ when campto versus campto + hel are compared at each time point or as indicated. C, Quantitation of neuronal survival with BAY 11-7082 (12 hr) as assessed by nuclear counts under the conditions as indicated. 

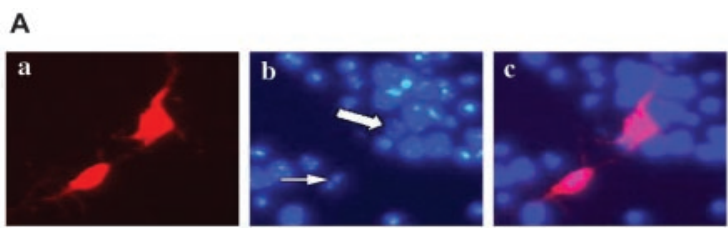

B

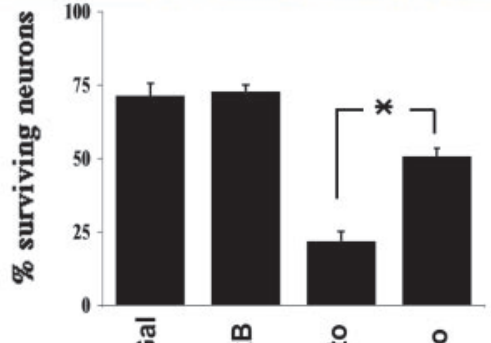
ত্লু 意 을 흘 흥 产

C

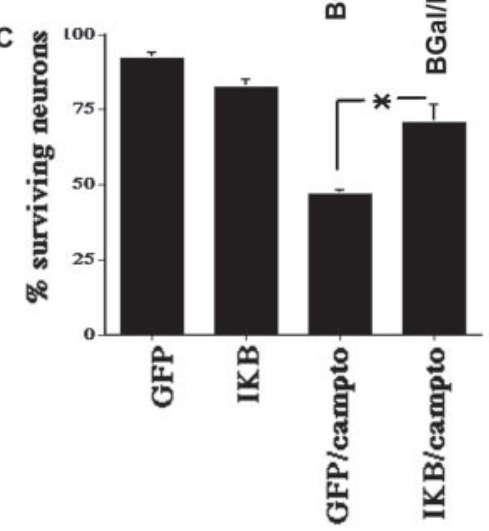

Figure 5. Inhibition of NF- $\kappa B$ by induction of $I_{\kappa} B S R$ protects primary cortical neurons against camptothecin-induced cell death. $A, B$, Primary cortical neurons were cotransfected with $\beta$-gal + empty $\mathrm{pcDNA3}$ vector $(\beta \mathrm{Gal})$ or $\beta$-gal $+\left.\right|_{\kappa} \mathrm{BSR}$ expressing $\mathrm{pcDNA3}$ $\left(\beta \mathrm{Gal}+I_{\kappa \mathrm{BSR}}\right)$ and treated with or without camptothecin (campto). Aa, Cultured cortical neurons were immunostained by anti- $\beta$-gal antibody (as described in Materials and Methods). $A b$, Nuclei were stained with Hoechst, a nuclear-specific fluorescent dye. $A c$, Merged micrograph of $a$ and $b$. Condensed or fragmented nuclei were scored as dead (shown by thin arrow) versus intact nuclei (shown by thick arrow). $B$, Quantitation of survival assay among indicated groups of cotransfected primary cortical neurons after $14 \mathrm{hr}$ of treatment with camptothecin. $C$, Identical experiment as in $A$ and $B$ with the exception that I $\kappa B S R$ was expressed via recombinant adenovirus. GFP, Green fluorescent protein; $I_{\kappa} B$, GFP-tagged $I_{\kappa} B S R$. Each data point is the mean \pm SEM of three independent cultures. ${ }^{*} p<0.05$ ( $t$ test).

maintenance, NF- $\kappa \mathrm{B}$ also may have a role in DNA damageinduced cell death.

Because pharmacological agents have the potential pitfall of nonspecific drug actions, we next investigated the functional importance of NF- $\kappa \mathrm{B}$, using a more specific molecular approach. As we previously mentioned, activation of NF- $\kappa \mathrm{B}$ requires its dissociation from the inhibitory molecule, I $\kappa \mathrm{B}$. Accordingly, we expressed a stable mutant super-repressive form of $\mathrm{I} \kappa \mathrm{B}-\alpha\left(\mathrm{Ser}^{32} /\right.$ Ser ${ }^{36}$-to-alanine mutant; I $\kappa$ BSR) and evaluated its effects on neuronal death. Cultured cortical neurons were cotransfected with a plasmid construct, expressing $\mathrm{I} \kappa \mathrm{BSR}$, along with $\beta$-galexpressing plasmid, as a marker to determine the transfected cells. In this experiment the time between transfection and start of camptothecin treatment was shortened to eliminate any potential effects of prolonged $\mathrm{I} \kappa \mathrm{B}$ effects on neuronal survival. Accordingly, $16 \mathrm{hr}$ after transfection (a time at which $\mathrm{I} \kappa \mathrm{B}$ expression was observed) neuronal cultures were treated with camptothecin

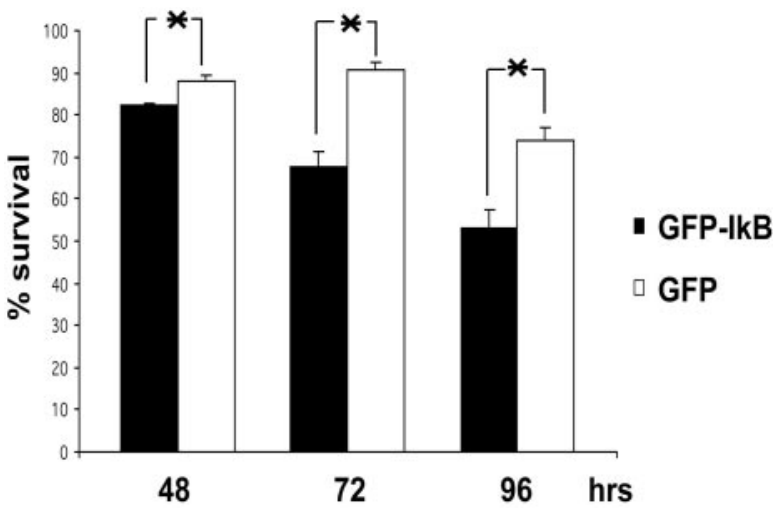

Figure 6. Chronic expression of $\mid \kappa B S R$ results in neuronal death. Embryonic cortical neurons were infected with either GFP or GFP-tagged $I_{\kappa B S R}$ expressing adenoviruses at the time of plating $(\mathrm{MOI}=250)$. At 48, 72, and $96 \mathrm{hr}$ after plating the neuronal cultures were fixed, and GFP-containing neurons were assessed for survival by analyses of nuclear integrity. Each data point is the mean \pm SEM of three independent cultures. ${ }^{*} p<0.05$ ( $t$ test).

for $14 \mathrm{hr}$. Then the neuronal cultures were fixed and analyzed by immunocytochemistry via an anti- $\beta$-gal antibody and evaluated for nuclear morphology by Hoechst staining. Cells with condensed or fragmented nuclei were scored as dead (Fig. 5A). As shown in Figure $5 B$, cells cotransfected with $\beta$-gal and $\mathrm{I} \kappa \mathrm{BSR}$ ( $\sim 50 \%$ survival) were considerably more resistant to death induced by camptothecin than those transfected with $\beta$-gal alone ( $20 \%$ survival). To support the notion that the protective effects of I $\kappa$ BSR were not an artifact of the transfection methodology, we also chose to deliver a GFP-tagged $\mathrm{I} \kappa \mathrm{BSR}$ fusion protein via recombinant adenovirus. Primary cortical neurons were infected at the time of plating. After $16 \mathrm{hr}$ the cultures were treated with camptothecin for $14 \mathrm{hr}$, and GFP-positive neurons were evaluated for death. As shown in Fig. $5 C$, protection with I $\kappa$ BSR was comparable to that achieved with transfection.

The above evidence suggests that the NF- $\kappa \mathrm{B}$ pathway plays a role in neuronal damage. However, as mentioned previously, our results with the use of pharmacological NF- $\kappa \mathrm{B}$ inhibitors also suggest that NF- $\kappa \mathrm{B}$ activation may activate pro-survival signals. In this regard, prolonged expression of I $\kappa$ BSR (over $48-72 \mathrm{hr}$ ) gradually results in neuronal death (Fig. 6). This is consistent with the observation that prolonged exposure to pharmacological NF- $\kappa \mathrm{B}$ inhibitors alone also induces death. In this case it is important to note that death induced by the NF- $\kappa \mathrm{B}$ pharmacological inhibitors is slightly more rapid than with $\mathrm{I} \kappa \mathrm{B}$ expression. This may be attributable to the fact that it takes more time to synthesize sufficient $\mathrm{I} \kappa \mathrm{B}$ to inhibit the NF- $\kappa \mathrm{B}$ genes required for neuronal maintenance and/or that the rapid onset of NF- $\kappa \mathrm{B}$ inhibition with pharmacological inhibitors may be more efficient at inducing toxicity. Nonetheless, the observation that multiple NF- $\kappa \mathrm{B}$ inhibitors as well as $\mathrm{I} \kappa \mathrm{B}$ expression both protect from exogenous insults and also induce death on its own suggests that NF- $\kappa$ B serves a dual role: neuronal maintenance under basal conditions and signaling for death under conditions of acute hyperactivation caused by DNA damage.

The complexity of NF- $\kappa \mathrm{B}$ signaling is underscored by our observations with the use of p50- or p65-deficient neurons. Cortical neurons were obtained from mice deficient in either the $\mathrm{p} 50$ or p $65 \mathrm{NF}-\kappa \mathrm{B}$ subunits and evaluated for death after DNA damage. Both p50- and p65-deficient neurons did not show any resistance or sensitivity to death after camptothecin treatment (Fig. $7 A, B)$. Interestingly, neurons obtained from p50 or p65 knockout mice showed healthy soma and neurites in culture in the 

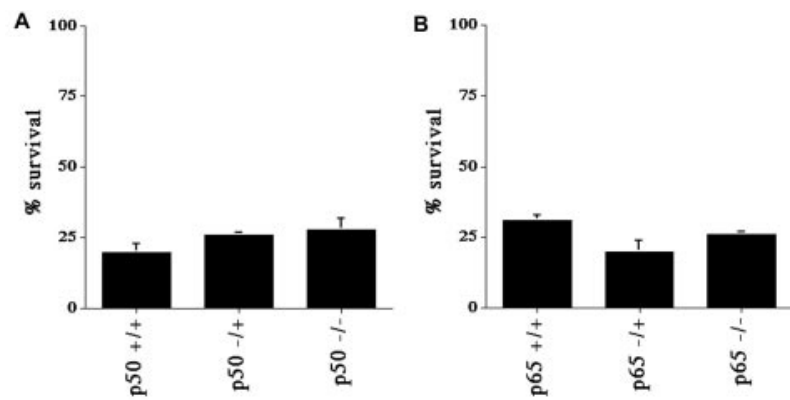

Figure 7. $\quad$ p50 or p65 deficiency is not protective against camptothecin-induced neuronal death. Cortical neurons were obtained from embryos derived from a double heterozygote breeding of either p50 $(A)$ or p65 $(B)$. Cultures were exposed to camptothecin for $14 \mathrm{hr}$ and analyzed by nuclear counts. Each data point is the mean \pm SEM from three independent embryos.

absence of DNA damage and displayed normal basal levels of survival. The results suggest that single deletions of either $\mathrm{p} 50$ or p65 have no effects on neuronal survival or death and/or compensatory mechanisms of NF- $\kappa \mathrm{B}$ action (to be discussed further below). However, NF- $\kappa$ B DNA binding activity (as observed by EMSA as in Fig. 1) was not detected in extracts from p50 neurons treated with DNA damage (data not shown). This suggests that, although gross NF- $\kappa \mathrm{B}$ induction by DNA damage is abolished in these NF- $\kappa \mathrm{B}$-deficient neurons, some germline compensation allows for death to proceed. To determine more definitively the role of NF- $\kappa \mathrm{B}$ in neuronal death induced by DNA damage and to avoid any compensatory issues associated with germline deficiencies inherent in knock-out mice, we more acutely suppressed the expression of p65, using an RNAi strategy. p65-specific RNAi, but not a scrambled control or transfection reagent alone, reduced the level of this protein (Fig. 8). Importantly, p65 downregulation by RNAi also provided significant protection against DNA damage (Fig. 8). This finding is consistent with our observations with $\mathrm{I} \kappa \mathrm{B}$ expression and pharmacological inhibitors and supports a pro-apoptotic role for acute NF- $\kappa \mathrm{B}$ activation in DNA damage.

\section{p53 as a required downstream effector of NF- $\kappa$ B in camptothecin-induced neuronal death}

We next explored the potential mechanisms by which NF- $\kappa \mathrm{B}$ may induce death after DNA damage. We have shown previously that p53 is induced after camptothecin exposure (Morris et al., 2001). We first evaluated whether coadministration of the NF- $\kappa \mathrm{B}$ inhibitors CAPE or helenalin with camptothecin would affect p53 induction. As shown in Figure 9A, both inhibitors effectively blocked the induction of p53 as compared with cultures treated with camptothecin alone. To ensure that these effects were specific to NF- $\kappa$ B inhibition, we also examined for p53 induction in $\mathrm{I} \kappa \mathrm{BSR}$-expressing neurons. Neuronal cultures were infected with adenovirus expressing either GFP-tagged I $\kappa$ BSR or GFP. Cultures were exposed to camptothecin for $8 \mathrm{hr}$ to induce p53 levels. After fixation the GFP-positive neurons then were evaluated for p53 by immunofluorescence staining. The ratio of p53-positive GFP-positive cells to p53-negative GFP-positive cells was determined. As shown in Figure 9C, GFP-expressing cultures displayed almost four times the ratio of p53-positive cells as compared with GFP-tagged $\mathrm{I} \kappa \mathrm{BSR}$-expressing cells. Taken together, these results indicate that NF- $\kappa \mathrm{B}$ inhibition by pharmacological inhibitors or $\mathrm{I} \kappa \mathrm{BSR}$ expression results in decreased p53 induction.
The elevation in p53 levels is accompanied by an increase in p53-inducible genes. The induction of the Bcl-2 family members Puma and Noxa is dependent on p53 (Oda et al., 2000; Yu et al., 2001). As shown in Figure $10 A$, the induction of these genes (as determined by RT-PCR) after camptothecin treatment is reduced dramatically with cotreatment with the NF- $\kappa$ B inhibitor helenalin, which is also effective in promoting survival (Fig. 4). These results indicate that NF- $\kappa \mathrm{B}$ actions occur upstream of p53 to regulate both p53 levels and activity. Consistent with this interpretation, adenoviral-mediated p53 expression induces death even in the presence of the NF- $\kappa \mathrm{B}$ inhibitor helenalin (Fig. $10 \mathrm{~B}$ ). Finally, we examined whether NF- $\kappa \mathrm{B}$ may affect transcription of p53 directly. As shown in Figure 11, p53 transcripts, as measured by RT-PCR, increase after exposure to DNA damage. This increase was abolished with cotreatment with the NF- $\kappa \mathrm{B}$ inhibitor helenalin.

Our results described above strongly suggest that the protective effects of acute NF- $\kappa$ B inhibition in the presence of DNA damage occur via transcriptional modulation of p53. Interestingly, we also examined whether p53 is modulated in p65deficient neurons that are not resistant to DNA damage-induced death. As shown in Figure 9B, the data clearly indicate that the increase in p53 levels is not affected by p65 deficiency when compared with littermate controls. Similarly, the IKK inhibitor BAY 11-7082 (Pierce et al., 1997), which was not protective, also failed to block p53 induction (Fig. 9A) and the induction of the p53inducible genes Puma and Noxa (Fig. 10A). This evidence is consistent with the relationship between p53 inhibition and resistance to DNA damage-induced death.

\section{Discussion}

Our previous work in a cortical model of neuronal death evoked by the DNA-damaging agent camptothecin has provided a signaling framework by which CDKs and p53 coordinate to activate the conserved mitochondrial pathway of death (Bax activation, cytochrome $c$ release, caspase activation) (Morris et al., 2001). However, key questions remain. For example, how are these signals activated and how do they control the Bax activation? The present examination of NF- $\kappa \mathrm{B}$ was undertaken for several reasons. First, previous reports indicated potential interactions of NF- $\kappa \mathrm{B}$ with both $\mathrm{p} 53$ and CDKs. For example, NF- $\kappa \mathrm{B}$ regulates the expression of cyclinD1, a binding partner required for CDK4/6 activation. It also interacts directly with $\mathrm{pRb}$, stimulating NF- $\kappa \mathrm{B}$ DNA binding, but suppresses transcriptional activity (Tamami et al., 1996). Similarly, NF- $\kappa$ B potentially can regulate p53-mediated processes. For example, NF- $\kappa$ B can regulate expression of p53 directly via $\kappa \mathrm{B}$ sites in the promoter sequence of the p53 gene (Wu and Lozano, 1994; Kirch et al., 1999; Qin et al., 1999; Benoit et al., 2000). Second, NF- $\kappa$ B modulates other life/ death signaling pathways via expression and/or repression of a myriad of pro- or anti-apoptotic genes (for review, see Barkett and Gilmore, 1999). Our present results show that (1) NF- $\kappa$ B activation occurs via degradation of $\mathrm{I} \kappa \mathrm{B}$; (2) this activation that occurs is likely independent of IKK, ATM, p53, and CDK activation; (3) functionally, NF- $\kappa$ B serves a dual role in neurons. In the presence of DNA damage, inhibition of the NF- $\kappa$ B pathway by $\mathrm{NF}-\kappa \mathrm{B}$ inhibitors or I $\kappa \mathrm{BSR}$ expression is protective by a mechanism involving suppression of p53 induction. However, in the absence of such stress, long-term inhibition of NF- $\kappa \mathrm{B}$ leads to neuronal death, suggesting an alternative role in neuronal maintenance. 


\section{Control of activation of NF- $\kappa \mathrm{B}$}

Our results clearly demonstrate activation of NF- $\kappa \mathrm{B}$ after DNA damage. We have demonstrated a rapid increase in NF- $\kappa \mathrm{B}$ DNA binding as early as $2 \mathrm{hr}$ after camptothecin treatment. Importantly, NF- $\kappa \mathrm{B}$ activation occurs before the neuronal commitment point of death, which we have defined previously as $\sim 4-6 \mathrm{hr}$ after camptothecin treatment. This indicates that, at least temporally, NF- $\kappa \mathrm{B}$ activation occurs at a time sufficiently early to modulate death commitment.

In this death paradigm the activation of $\mathrm{NF}-\kappa \mathrm{B}$ likely is mediated via the loss of $\mathrm{I} \kappa \mathrm{B}$. How is the loss of $\mathrm{I} \kappa \mathrm{B}$ regulated? There are several possibilities in this regard. First, phosphorylation of $\mathrm{I} \kappa \mathrm{B}-\alpha$ on two conserved serine residues $\left(\operatorname{Ser}^{32}\right.$ and $\mathrm{Ser}^{36}$ in human and mouse $\left.\mathrm{I} \kappa \mathrm{B}-\alpha\right)$ in the $\mathrm{N}$-terminal regulatory domain of $\mathrm{I} \kappa \mathrm{B}$ results in ubiquitination and consequent proteasomal-mediated degradation. Phosphorylation of $\mathrm{I} \kappa \mathrm{B}-\alpha$ occurs via I $\kappa \mathrm{B}$ kinase complex (IKK) or, in select circumstances of p53-mediated death, via pp90 ${ }^{\text {rsk }}$ (in-

volved in the RAF/MAPK cascade) (Ghoda et al., 1997; Ryan et al., 2000). However, our evidence does not support the regulation of $\mathrm{I} \kappa \mathrm{B}$ via this phosphorylation-mediated mechanism. For example, the IKK inhibitor BAY 11-7082 (Pierce et al., 1997), does not protect neurons from camptothecin-induced damage, and we could not detect an increase in phosphorylation of $\mathrm{I} \kappa \mathrm{B}-\alpha$. This suggests that the classical IKK pathway and/or phosphorylation on $\mathrm{Ser}^{32} / \mathrm{Ser}^{36}$ may not play a role in $\mathrm{NF}-\kappa \mathrm{B}$ regulation after DNA damage. Alternative pathways of $\mathrm{I} \kappa \mathrm{B}$ regulation include calpain-mediated cleavage (Miyamoto et al., 1998; McDonald et al., 2001), phosphorylation of tyrosine 42, which has been reported to release NF- $\kappa \mathrm{B}$ from $\mathrm{I} \kappa \mathrm{B}-\alpha$ without subsequent proteolytic degradation (Imbert et al., 1996), or redox-dependent $\mathrm{I} \kappa \mathrm{B}$ degradation (Kretz-Remy et al., 1998; Das, 2001). In addition, it is possible that other members of $\mathrm{I} \kappa \mathrm{B}$ family also may play a critical role in regulation of $\mathrm{NF}-\kappa \mathrm{B}$. Careful examination of these possibilities will be of importance in future studies.

Importantly, NF- $\kappa \mathrm{B}$ activation is not regulated directly by ATM, p53, or CDKs. This observation is of particular interest because of previous reports implicating ATM and p53 as activators of NF- $\kappa$ B activation (Piret et al., 1999; Li et al., 2001) and CDK-mediated regulation of NF- $\kappa \mathrm{B}$ via the $\mathrm{p} 300$ and CBP coactivators (Perkins et al., 1997). The relationship among ATM, p53, CDKs, and NF- $\kappa \mathrm{B}$ is clearly different in the present context. For example, it is more likely that the NF- $\kappa \mathrm{B}$ pathway is parallel to the CDK pathway while it activates the p53 response.

\section{Function of NF- $\kappa \mathrm{B}$ in neuronal survival and death}

The biological activity of NF- $\kappa \mathrm{B}$ is complex in regard to cell survival or death. For example, NF- $\kappa \mathrm{B}$ has been shown to have differential effects in response to distinct death initiators (Lin et al., 1998). In cultured cortical neurons our evidence indicates that $\mathrm{NF}-\kappa \mathrm{B}$ plays a dual role in neurons, depending on the context and the manner by which NF- $\kappa \mathrm{B}$ activity is manipulated. Several pieces of evidence support this. First, under normal basal conditions the prolonged expression of $\mathrm{I} \kappa \mathrm{B}$ as well as pharmacological inhibitors of NF- $\kappa$ B leads to loss of neurites and neuronal death. This is consistent with several reports indicating that a sustained basal activation of NF- $\kappa$ B is necessary in cortical neurons as well as other neuronal cell types (Hamanoue et al., 1999; Bhakar et al., 2002). For instance, Maggirwar et al. (1998) have shown that nerve growth factor-dependent (NGF) activation of NF- $\kappa \mathrm{B}$ contributes to survival of cultured sympathetic neurons and that NF- $\kappa \mathrm{B}$ suppression can be protective against NGF deprivation in that model.

However, with acute exposure to camptothecin the downregulation of NF- $\kappa \mathrm{B}$ is transiently protective. The mechanism by which this occurs is likely via attenuation of p53 levels. Consistent with this, we have shown that p53 deficiency protects cortical neurons from DNA damage (Morris et al., 2001). In addition, our present data indicate that suppression of NF- $\kappa \mathrm{B}$ pathways by multiple means diminishes p53 transcription and activity. Indeed, $\kappa \mathrm{B}$ binding sites on the $\mathrm{p} 53$ promoter have been described, and NF- $\kappa \mathrm{B}$ has been reported to activate transcription of the p53 gene (Hellin et al., 1998; Pei et al., 1999; Zhang et al., 2001). ІкB also may regulate p53 by direct physical interaction (Chang, 2002). However, the fact that we could not detect cytoplasmic sequestration of p53 (our unpublished data) makes this possibility unlikely. The present findings are further consistent with reports indicating that NF- $\kappa \mathrm{B}$ in the presence of $\mathrm{p} 53$ serves a proapoptotic function (Ryan et al., 2000).

It is important to note that understanding the role of NF- $\kappa \mathrm{B}$ pathways in neuronal death/survival is a function of the manner by which NF- $\kappa \mathrm{B}$ is altered. This reflects the dual nature of NF- $\kappa \mathrm{B}$ in regard to death and survival (Wang et al., 1996). For example, although our present results suggest that downregulation of $\mathrm{NF}-\kappa \mathrm{B}$ results in survival, a previous report suggested that overexpression of p65 also leads to protection in neurons exposed to DNA damage (Bhakar et al., 2002). The likely explanation for these differences is that the induction of specific NF- $\kappa \mathrm{B}$ regulated genes is activated differentially, depending on subunit composition, strength, and duration of NF- $\kappa \mathrm{B}$ activation. For example, p65 overexpression is known to upregulate pro-survival 
A.



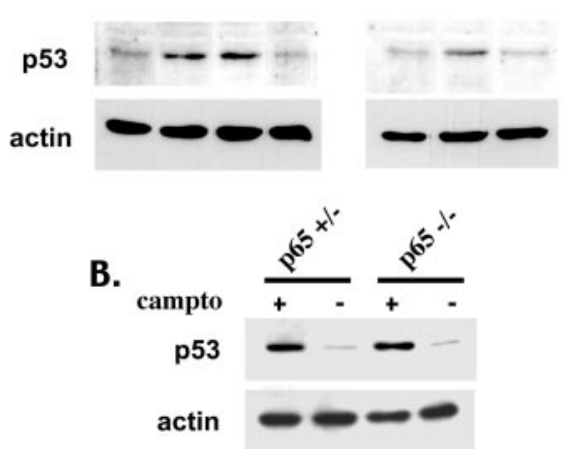

C.
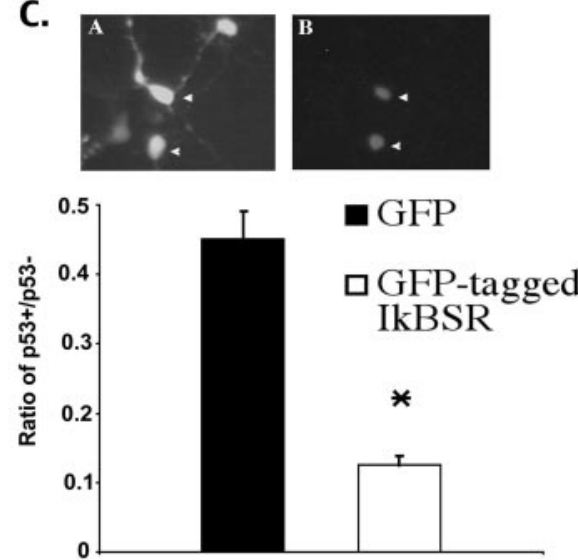

Figure 9. The effect of NF- $\kappa$ B suppression on $p 53$ activation after camptothecin treatment. $A$, Cultured cortical neurons were treated for $8 \mathrm{hr}$ with camptothecin $(10 \mu \mathrm{M})$ or cotreated with indicated pharmacological inhibitors of NF- $\kappa$ B. Total protein extracts were probed for $\mathrm{p} 53$ in a Western blot analysis. $B$, Cortical neurons, which had been harvested from $14.5 \mathrm{~d}$ littermate embryos of indicated p65 genotypes, were subjected to camptothecin or vehicle treatment for $8 \mathrm{hr}$. Protein extracts were probed for $p 53$. $\beta$-Actin was used as a loading control. C, Expression of $\mid \kappa B S R$ inhibits p53 induction. Cortical neurons were infected with GFP or GFP-tagged $\kappa_{\kappa B S R}$ expressing adenoviruses ( $\mathrm{MOI}=250)$ at the time of plating. At $24 \mathrm{hr}$ after plating they were treated with camptothecin $(10 \mu \mathrm{m})$ for $8 \mathrm{hr}$ to induce $\mathrm{p} 53$. Neurons were fixed and immunostained for p53. Neurons that expressed GFP (left panel) and nuclear p53 (right panel) were scored as positive (indicated with arrowheads). Neurons that expressed GFP but displayed no p53 signal were scored as negative. Bar graph representing quantitation of p53-positive neurons in cells expressing GFP control or GFP- $\mid \kappa B S R$ is indicated below the panels. Each data point is the mean \pm SEM of three independent experiments. ${ }^{*} p<0.05$ ( $t$ test).

signals such as the IAPs as well as $I \kappa B$ itself in DNA-damaged neurons, whereas downregulation of NF- $\kappa \mathrm{B}$ signaling, as presented here, inhibits p53 induction. Indeed, the contribution of $\mathrm{NF}-\kappa \mathrm{B}$ to either survival or death may depend on specific subunit composition of NF- $\kappa \mathrm{B}$ at specific endogenous NF- $\kappa \mathrm{B}$-regulated promoter sites, as reported in other paradigms (Cheng et al., 1994). Although our own present studies indicate that camptothecin activates the $\mathrm{p} 65 / \mathrm{p} 50 \mathrm{NF}-\kappa \mathrm{B}$ dimer (at least as observed by EMSA), it does not provide a comprehensive picture of how $\mathrm{NF}-\kappa \mathrm{B}$ is regulated at specific promoter sites during death.

Importantly, neurons obtained from p65- or p50-deficient mice show no resistance or sensitization to camptothecininduced death, nor were they different in apparent size, general appearance, neurite formation, and basal survival as compared with littermate control neurons. This lack of effect of p50/p65 deficiency may be attributable to the fact that other NF- $\kappa$ B sub-


Figure 10. A, The 065 inhibitor helenalin (Hel), but not the IKK inhibitor BAY 11-7082 (Bay), inhibits the p53-inducible genes Noxa and Puma. Cortical neurons were treated with camptothecin with and without cotreatment as indicated for $12 \mathrm{hr}$. Noxa and Puma levels then were analyzed by RT-PCR as described in Results. S12 (a ribosomal protein used as a loading control) also was analyzed as a negative control, which did not change during camptothecin treatment. $B$, Adenoviral-mediated expression of $p 53$ still induces death even in the presence of the NF- $\kappa$ B inhibitor helenalin (Hel; $5 \mu \mathrm{m}$ ). Neurons were infected with adenovirus expressing lacZ control or p53 as indicated in Materials and Methods. Camptothecin treatment was initiated $24 \mathrm{hr}$ after infection. Survival was assessed at $12 \mathrm{hr}$ after camptothecin treatment in the presence or absence of helenalin. Inset demonstrates the overexpression of p53. Lane 1, Infection with p53-expressing virus; lane 2, infection with lacZ control; lane 3 , no infection. ${ }^{*} p<0.05$ ( $t$ test).

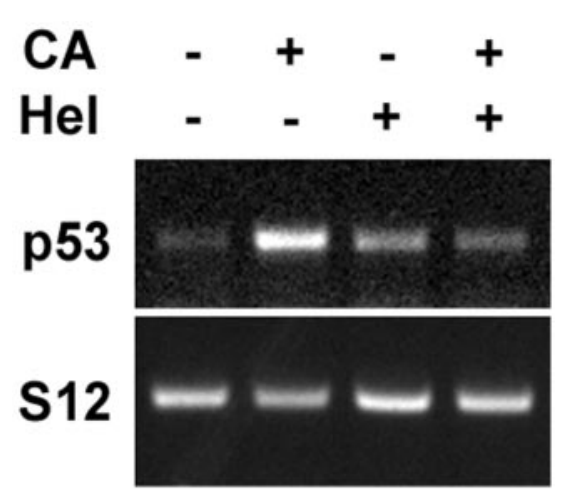

Figure 11. NF- $\kappa$ B inhibition blocks induction of $p 53$ transcripts induced by DNA damage. Cortical neurons were treated with camptothecin with and without cotreatment with helenalin (Hel; $5 \mu \mathrm{M}$ ) as indicated for $2 \mathrm{hr}$. Then p53 transcription levels were analyzed by RT-PCR as described in Results. S12 (a ribosomal protein used as a loading control) also was analyzed as a negative control, which did not change during camptothecin treatment. 
units in addition to p65/p50 may compensate for single subunit deficiencies. In this regard, numerous additional forms of Rel/ NF- $\kappa \mathrm{B}$ proteins have been described (e.g., c-Rel, Rel-B, p52, and NKBF, a neuron-specific $\kappa \mathrm{B}$ factor) (Moerman et al., 1999). However, our results demonstrating protection with more acute downregulation of $\mathrm{p} 65$ by RNAi suggest that this is not the case. Alternatively, germline compensation not directly related to $\mathrm{NF}-\kappa \mathrm{B}$ in p65- or p50-deficient mice may mask normal NF- $\kappa \mathrm{B}$ function. Regardless of the reason, it is important to note that p65- or p50-deficient neurons did not show an attenuated p53 response when compared with littermate controls. This is consistent with the notion that reduction of p53 activation is important for the survival effects observed by overexpression of $\mathrm{I} \kappa \mathrm{B}$ or general NF- $\kappa \mathrm{B}$ inhibitors.

In summary, our results support a model by which NF- $\kappa \mathrm{B}$ can serve both a pro-apoptotic and pro-survival function. We hypothesize that a basal level of NF- $\kappa \mathrm{B}$ activity is important for proper neuronal maintenance and survival under normal conditions. However, in the presence of a DNA damage stimulus NF- $\kappa \mathrm{B}$ participates in the induction of p53 and therefore serves an acute pro-apoptotic function. Accordingly, the ultimate prognosis of damaged neurons is modulated by the balance between these two simultaneous and opposing roles of NF- $\kappa \mathrm{B}$. Moreover, this model would serve to explain the controversial nature of $\mathrm{NF}-\kappa \mathrm{B}$ in neuronal death and survival.

\section{References}

Alam ZI, Jenner A, Daniel SE, Lees AJ, Cairns N, Marsden CD, Jenner P, Halliwell B (1997) Oxidative DNA damage in the parkinsonian brain: an apparent selective increase in 8-hydroxyguanine levels in substantia nigra. J Neurochem 69:1196-1203.

Bales KR, Du Y, Dodel RC, Yan GM, Hamilton-Byrd E, Paul SM (1998) The NF-kappaB/Rel family of proteins mediates $\mathrm{A} \beta$-induced neurotoxicity and glial activation. Brain Res Mol Brain Res 57:63-72.

Barkett M, Gilmore TD (1999) Control of apoptosis by Rel/NF-kappaB transcription factors. Oncogene 18:6910-6924.

Barnes DE, Stamp G, Rosewell I, Denzel A, Lindahl T (1998) Targeted disruption of the gene encoding DNA ligase IV leads to lethality in embryonic mice. Curr Biol 8:1395-1398.

Benoit V, Hellin AC, Huygen S, Gielen J, Bours V, Merville MP (2000) Additive effect between NF-kappaB subunits and $\mathrm{p} 53$ protein for transcriptional activation of human p53 promoter. Oncogene 19:4787-4794.

Bhakar AL, Tannis L-L, Zeindler C, Russo MP, Jobin C, Park DS, MacPherson $S$, Barker PA (2002) Constitutive nuclear factor- $\kappa \mathrm{B}$ activity is required for central neuron survival. J Neurosci 22:8466-8475.

Bogdanov M, Brown RH, Matson W, Smart R, Hayden D, O'Donnell H, Flint Beal M, Cudkowicz M (2000) Increased oxidative damage to DNA in ALS patients. Free Radic Biol Med 29:652-658.

Chang NS (2002) The non-ankyrin C terminus of I $\kappa$ B- $\alpha$ physically interacts with p53 in vivo and dissociates in response to apoptotic stress, hypoxia, DNA damage, and transforming growth factor- $\beta 1$-mediated growth suppression. J Biol Chem 277:10323-10331.

Cheema ZF, Wade SB, Sata M, Walsh K, Sohrabji F, Miranda RC (1999) Fas/Apo [apoptosis] -1 and associated proteins in the differentiating cerebral cortex: induction of caspase-dependent cell death and activation of NF- $\kappa$ B. J Neurosci 19:1754-1770.

Chen J, Jin K, Chen M, Pei W, Kawaguchi K, Greenberg DA, Simon RP (1997) Early detection of DNA strand breaks in the brain after transient focal ischemia: implications for the role of DNA damage in apoptosis and neuronal cell death. J Neurochem 69:232-245.

Cheng Q, Cant C, Moll T, Hofer-Warbinek R, Wagner E, Birnstiel M, Bach F, de Martin R (1994) NK- $\kappa$ B subunit-specific regulation of the I $\kappa \mathrm{B}-\alpha$ promoter. J Biol Chem 269:13551-13557.

Clemens JA, Stephenson DT, Dixon EP, Smalstig EB, Mincy RE, Rash KS, Little SP (1997) Global cerebral ischemia activates nuclear factorkappaB prior to evidence of DNA fragmentation. Brain Res Mol Brain Res 48:187-196.

Cosi C, Marien M (1999) Implication of poly(ADP-ribose) polymerase (PARP) in neurodegeneration and brain energy metabolism. Decreases in mouse brain $\mathrm{NAD}^{+}$and ATP caused by MPTP are prevented by the PARP inhibitor benzamide. Ann NY Acad Sci 890:227-239.

Cosi C, Suzuki H, Skaper SD, Milani D, Facci L, Menegazzi M, Vantini G, Kanai Y, Degryse A, Colpaert F, Koek W, Marien MR (1997) Poly(ADPribose) polymerase (PARP) revisited. A new role for an old enzyme: PARP involvement in neurodegeneration and PARP inhibitors as possible neuroprotective agents. Ann NY Acad Sci 825:366-379.

Cui J, Holmes EH, Greene TG, Liu PK (2000) Oxidative DNA damage precedes DNA fragmentation after experimental stroke in rat brain. FASEB J 14:955-967.

Das KC (2001) c-Jun $\mathrm{NH}_{2}$-terminal kinase-mediated redox-dependent degradation of I $\kappa$ B. J Biol Chem 276:4662-4670.

Deans B, Griffin CS, Maconochie M, Thacker J (2000) Xrcc2 is required for genetic stability, embryonic neurogenesis, and viability in mice. EMBO J 19:6675-6685.

Fortin A, Cregan SP, MacLaurin JG, Kushwaha N, Hickman ES, Thompson CS, Hakim A, Albert PR, Cecconi F, Helin K, Park DS, Slack RS (2001) APAF1 is a key transcriptional target for p53 in the regulation of neuronal cell death. J Cell Biol 155:207-216.

Gabbita SP, Lovell MA, Markesbery WR (1998) Increased nuclear DNA oxidation in the brain in Alzheimer's disease. J Neurochem 71:2034-2040.

Gao Y, Sun Y, Frank KM, Dikkes P, Fujiwara Y, Seidl KJ, Sekiguchi JM, Rathbun GA, Swat W, Wang J, Bronson RT, Malynn BA, Bryans M, Zhu C, Chaudhuri J, Davidson L, Ferrini R, Stamato T, Orkin SH, Greenberg ME, Alt FW (1998) A critical role for DNA end-joining proteins in both lymphogenesis and neurogenesis. Cell 95:891-902.

Ghoda L, Lin X, Greene WC (1997) The $90 \mathrm{kDa}$ ribosomal S6 kinase $\left(\mathrm{pp} 90^{\mathrm{rsk}}\right)$ phosphorylates the N-terminal regulatory domain of $\mathrm{I} \kappa \mathrm{B}-\alpha$ and stimulates its degradation in vitro. J Biol Chem 272:21281-21288.

Giovanni A, Keramaris E, Morris EJ, Hou ST, O'Hare M, Dyson N, Robertson GS, Slack RS, Park DS (2000) E2F1 mediates death of $\beta$-amyloid-treated cortical neurons in a manner independent of p53 and dependent on bax and caspase 3. J Biol Chem 275:11553-11560.

Gu Y, Sekiguchi J, Gao Y, Dikkes P, Frank K, Ferguson D, Hasty P, Chun J, Alt FW (2000) Defective embryonic neurogenesis in Ku-deficient but not DNA-dependent protein kinase catalytic subunit-deficient mice. Proc Natl Acad Sci USA 97:2668-2673.

Hamanoue M, Middleton G, Wyatt S, Jaffray E, Hay RT, Davies AM (1999) p75-Mediated NF- $\kappa$ B activation enhances the survival response of developing sensory neurons to nerve growth factor. Mol Cell Neurosci 14:28-40.

Hardy S, Kitamura M, Harris-Stansil T, Dai Y, Phipp ML (1997) Construction of adenovirus vectors through Cre-lox recombination. J Virol 71: 1842-1849.

Hellin AC, Calmant P, Gielen J, Bours V, Merville MP (1998) Nuclear factor- $\kappa \mathrm{B}$-dependent regulation of $\mathrm{p} 53$ gene expression induced by daunomycin genotoxic drug. Oncogene 16:1187-1195.

Imbert V, Rupec RA, Livolsi A, Pahl HL, Traenckner EB, Mueller-Dieckmann C, Farahifar D, Rossi B, Auberger P, Baeuerle PA, Peyron JF (1996) Tyrosine phosphorylation of IkappaB-alpha activates NF-kappaB without proteolytic degradation of IkappaB-alpha. Cell 86:787-798.

Jenner P (1998) Oxidative mechanisms in nigral cell death in Parkinson's disease. Mov Disord 13:24-34

Joyce D, Albanese C, Steer J, Fu M, Bouzahzah B, Pestell RG (2001) NF- $\kappa$ B and cell-cycle regulation: the cyclin connection. Cytokine Growth Factor Rev 12:73-90.

Karin M (1999) The beginning of the end: I $\kappa$ B kinase (IKK) and NF- $\kappa$ B activation. J Biol Chem 274:27339-27342.

Kenmochi N, Kawaguchi T, Rozen S, Davis E, Goodman N, Hudson TJ, Tanaka T, Page DC (1998) A map of 75 human ribosomal protein genes. Genome Res 8:509-523.

Keramaris E, Hirao A, Slack RS, Mak TW, Park DS (2003) Ataxia telangiectasia-mutated can regulate $\mathrm{p} 53$ and neuronal death independent of Chk2 in response to DNA damage. J Biol Chem 278:37782-37789.

Kirch HC, Flaswinkel S, Rumpf H, Brockmann D, Esche H (1999) Expression of human $p 53$ requires synergistic activation of transcription from the $p 53$ promoter by $\mathrm{AP}-1, \mathrm{NF}-\kappa \mathrm{B}$, and Myc/Max. Oncogene 18:2728-2738.

Kretz-Remy C, Bates EEM, Arrigo A-P (1998) Amino acid analogs activate $\mathrm{NF}-\kappa \mathrm{B}$ through redox-dependent $\mathrm{I} \kappa \mathrm{B}-\alpha$ degradation by the proteasome without apparent I $\kappa$ B- $\alpha$ phosphorylation. J Biol Chem 273:3180-3191.

LaCasse EC, Baird S, Korneluk RG, MacKenzie AE (1998) The inhibitors of 
apoptosis (IAPs) and their emerging role in cancer. Oncogene 17:3247-3259.

Li N, Banin S, Ouyang H, Li GC, Courtois G, Shiloh Y, Karin M, Rotman G (2001) ATM is required for $\mathrm{I} \kappa \mathrm{B}$ kinase (IKKk) activation in response to DNA double-strand breaks. J Biol Chem 276:8898-8903.

Lin K-I, DiDonato JA, Hoffmann A, Hardwick JM, Ratan RR (1998) Suppression of steady-state, but not stimulus-induced, NF- $\kappa$ B activity inhibits alphavirus-induced apoptosis. J Cell Biol 141:1479-1487.

Lovell MA, Markesbery WR (2001) Ratio of 8-hydroxyguanine in intact DNA to free 8-hydroxyguanine is increased in Alzheimer disease ventricular cerebrospinal fluid. Arch Neurol 58:392-396.

Lyss G, Knorre A, Schmidt TJ, Pahl HL, Merfort I (1998) The antiinflammatory sesquiterpene lactone helenalin inhibits the transcription factor NF- $\kappa$ B by directly targeting p65. J Biol Chem 273:33508-33516.

Maggirwar SB, Sarmiere PD, Dewhurst S, Freeman RS (1998) Nerve growth factor-dependent activation of NF- $\kappa$ B contributes to survival of sympathetic neurons. J Neurosci 18:10356-10365.

Mattson MP, Goodman Y, Luo H, Fu W, Furukawa K (1997) Activation of NF- $\kappa \mathrm{B}$ protects hippocampal neurons against oxidative stress-induced apoptosis: evidence for induction of manganese superoxide dismutase and suppression of peroxynitrite production and protein tyrosine nitration. J Neurosci Res 49:681-697.

McDonald MC, Mota-Filipe H, Paul A, Cuzzocrea S, Abdelrahman M, Harwood S, Plevin R, Chatterjee PK, Yaqoob MM, Thiemermann C (2001) Calpain inhibitor I reduces the activation of nuclear factor-kappaB and organ injury/dysfunction in hemorrhagic shock. FASEB J 15:171-186.

Mecocci P, Polidori MC, Ingegni T, Cherubini A, Chionne F, Cecchetti R, Senin U (1998) Oxidative damage to DNA in lymphocytes from AD patients. Neurology 51:1014-1017.

Miyamoto S, Seufzer BJ, Shumway SD (1998) Novel IkappaB-alpha proteolytic pathway in WEHI231 immature B cells. Mol Cell Biol 18:19-29.

Moerman AM, Mao X, Lucas MM, Barger SW (1999) Characterization of a neuronal $\kappa \mathrm{B}$-binding factor distinct from NF- $\kappa \mathrm{B}$. Mol Brain Res 67:303-315.

Morris EJ, Keramaris E, Rideout HJ, Slack RS, Dyson NJ, Stefanis L, Park DS (2001) Cyclin-dependent kinases and p53 pathways are activated independently and mediate bax activation in neurons after DNA damage. J Neurosci 21:5017-5026.

Morrison RS, Wenzel HJ, Kinoshita Y, Robbins CA, Donehower LA, Schwartzkroin PA (1996) Loss of the p53 tumor suppressor gene protects neurons from kainate-induced cell death. J Neurosci 16:1337-1345.

Nakai M, Qin ZH, Chen JF, Wang Y, Chase TN (2000) Kainic acid-induced apoptosis in rat striatum is associated with nuclear factor-kappaB activation. J Neurochem 74:647-658.

Natarajan K, Singh S, Burke Jr TR, Grunberger D, Aggarwal BB (1996) Caffeic acid phenethyl ester is a potent and specific inhibitor of activation of nuclear transcription factor NF-kappaB. Proc Natl Acad Sci USA 93:9090-9095.

Oda E, Ohki R, Murasawa H, Nemoto J, Shibue T, Yamashita T, Tokino T, Taniguchi T, Tanaka N (2000) Noxa, a BH3-only member of the Bcl-2 family and candidate mediator of p53-induced apoptosis. Science 288:1053-1058.

Park DS, Morris EJ, Padmanabhan J, Shelanski ML, Geller HM, Greene LA
(1998) Cyclin-dependent kinases participate in death of neurons evoked by DNA-damaging agents. J Cell Biol 143:457-467.

Pei XH, Nakanishi Y, Takayama K, Bai F, Hara N (1999) Benzo[a]pyrene activates the human $\mathrm{p} 53$ gene through induction of nuclear factor- $\kappa \mathrm{B}$ activity. J Biol Chem 274:35240-35246.

Perkins ND, Felzien LK, Betts JC, Leung K, Beach DH, Nabel GJ (1997) Regulation of NF-kappaB by cyclin-dependent kinases associated with the p300 coactivator. Science 275:523-527.

Pianetti S, Arsura M, Romieu-Mourez R, Coffey RJ, Sonenshein GE (2001) Her-2/neu overexpression induces NF-kappaB via a PI3-kinase/Akt pathway involving calpain-mediated degradation of IkappaB-alpha that can be inhibited by the tumor suppressor PTEN. Oncogene 20:1287-1299.

Pierce JW, Schoenleber R, Jesmok G, Best J, Moore SA, Collins T, Gerritsen ME (1997) Novel inhibitors of cytokine-induced I $\kappa$ B- $\alpha$ phosphorylation and endothelial cell adhesion molecule expression show antiinflammatory effects in vivo. J Biol Chem 272:21096-21103.

Piret B, Schoonbroodt S, Piette J (1999) The ATM protein is required for sustained activation of NF-kappaB following DNA damage. Oncogene 18:2261-2271.

Qin ZH, Chen RW, Wang Y, Nakai M, Chuang DM, Chase TN (1999) Nuclear factor- $\kappa \mathrm{B}$ nuclear translocation upregulates c-Myc and p53 expression during NMDA receptor-mediated apoptosis in rat striatum. J Neurosci 19:4023-4033.

Robison SH, Bradley WG (1984) DNA damage and chronic neuronal degenerations. J Neurol Sci 64:11-20.

Ryan KM, Ernst MK, Rice NR, Vousden KH (2000) Role of NF-kappaB in p53-mediated programmed cell death. Nature 404:892-897.

Schneider A, Martin-Villalba A, Weih F, Vogel J, Wirth T, Schwaninger M (1999) NF-kappaB is activated and promotes cell death in focal cerebral ischemia. Nat Med 5:554-559.

Sugo N, Aratani Y, Nagashima Y, Kubota Y, Koyama H (2000) Neonatal lethality with abnormal neurogenesis in mice deficient in DNA polymerase beta. EMBO J 19:1397-1404.

Tamami M, Lindholm PF, Brady JN (1996) The retinoblastoma gene product $(\mathrm{Rb})$ induces binding of a conformationally inactive nuclear factor$\kappa$ B. J Biol Chem 271:24551-24556.

Tobita M, Nagano I, Nakamura S, Itoyama Y, Kogure K (1995) DNA singlestrand breaks in postischemic gerbil brain detected by in situ nick translation procedure. Neurosci Lett 200:129-132.

Wang C-Y, Mayo MW, Baldwin Jr AS (1996) TNF- and cancer therapyinduced apoptosis: potentiation by inhibition of NF-kappaB. Science 274:784-787.

Wu H, Lozano G (1994) NF- $\kappa$ B activation of p53. A potential mechanism for suppressing cell growth in response to stress. J Biol Chem 269:20067-20074.

Xia Z, Dudek H, Miranti CK, Greenberg ME (1996) Calcium influx via the NMDA receptor induces immediate early gene transcription by a MAP kinase/ERK-dependent mechanism. J Neurosci 16:5425-5436.

Yu J, Zhang L, Hwang PM, Kinzler KW, Vogelstein B (2001) PUMA induces the rapid apoptosis of colorectal cancer cells. Mol Cell 7:673-682.

Zhang LH, Youn HD, Liu JO (2001) Inhibition of cell cycle progression by the novel cyclophilin ligand sanglifehrin A is mediated through the NF$\kappa \mathrm{B}$-dependent activation of p53. J Biol Chem 276:43534-43540. 